\title{
SaCRed Mathematics
}

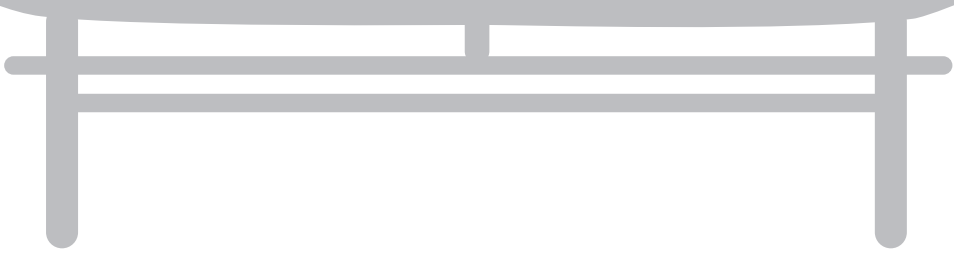




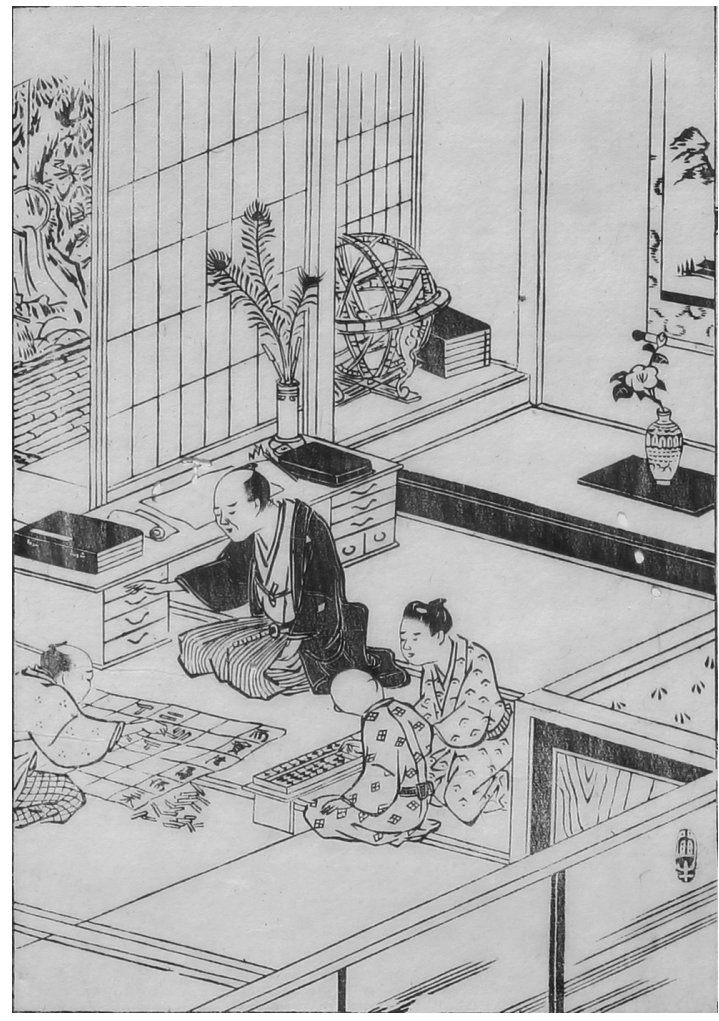

SACRED

Princeton University Press PrInCEton and OXford 


\section{Fukagawa Hidetoshi Tony Rothman}

112ATHEMATICS

\section{Japanese Temple Geometry}


Copyright (C 2008 by Princeton University Press

Published by Princeton University Press, 41 William Street,

Princeton, New Jersey 08540

In the United Kingdom: Princeton University Press,

3 Market Place, Woodstock,

Oxfordshire OX20 1SY

All Rights Reserved

ISBN 978-0-691-12745-3

British Library Cataloging-in-Publication Data is available

Library of Congress Cataloging-in-Publication Data

Fukagawa, Hidetoshi, 1943-

Sacred mathematics : Japanese temple geometry / Fukagawa

Hidetoshi, Tony Rothman.

p. $\mathrm{cm}$.

Includes bibliographical references.

ISBN 978-0-691-12745-3 (alk. paper)

1. Mathematics, Japanese-History. 2. Mathematics-Japan-

History-Tokugawa period, 1600-1868. 3. Mathematics-Problems,

exercises, etc. 4. Yamaguchi, Kazu, d. 1850. I. Rothman, Tony. II. Title.

$$
\begin{array}{cl}
\text { QA27.J3F849 } & 2008 \\
510.952-d c 22 & 2007061031
\end{array}
$$

This book has been composed in New Baskerville

Printed on acid-free paper. $\infty$ press.princeton.edu

Printed in the United States of America

$\begin{array}{llllllllll}1 & 3 & 5 & 7 & 9 & 10 & 8 & 6 & 4 & 2\end{array}$

Frontispiece: People enjoying mathematics. From the 1826 Sanpō Binran, or Handbook of Mathematics. (Courtesy Naoi Isao.) 


\section{To the Memory of Dan Pedoe}

Who first introduced sangaku to the world

Fukagawa Hidetoshi

\section{To Freeman Dyson}

For long friendship

Tony Rothman 
